\title{
8
}

\section{Crime in a Scandinavian Shopping Centre}

\author{
Vania Ceccato, Örjan Falk, Pouriya Parsanezhad, \\ and Väino Tarandi
}

\section{Introduction}

For many of us 'going shopping' is perceived to be an activity filled with great pleasure (Bamfield, 2012) as shopping centres have evolved from a group of stores to large enclosed malls with an eclectic number of services and functions (Savard \& Kennedy, 2014). The term shopping centre (or shopping malls) was originally used in North America to describe a group of shops or stores designed and developed as one architectural unit. Most recently, shopping centres are all over the world. They may be strip malls or giant complexes with stores, office complexes and cinemas as well as department stores, banks and schools. Regardless of their size or type, these facilities generate and attract crime (Bamfield, 2004; Brantingham

V. Ceccato $(\bowtie)$

Department of Urban Planning and Built Environment, KTH Royal Institute of Technology, Stockholm, Sweden

Ö. Falk • P. Parsanezhad • V. Tarandi

Real Estate and Construction Management, KTH Royal Institute of Technology, Stockholm, Sweden 
\& Brantingham, 1995). Yet, not all environments in a shopping centre are equally prone to crime (Bamfield, 2012; Poyner \& Webb, 1995; Savard \& Kennedy, 2014). Regardless of whether the risk of victimisation is real or not, little empirical research has looked at criminogenic conditions within shopping centres over time.

This study makes a contribution to a better understanding of the nature of crime in space and time in a shopping centre. This is done by first analysing a 17 month database from a security company with data on crime and incidents of public disturbance. In order to detect areas that run a higher risk of crime, crime and incidents of public disturbance are linked and mapped using a 3-D model by crime type, types of environments and time slices. Then, the study concludes by making suggestions to improve safety using CPTED principles as a theoretical reference. The three research questions are:

1. Which are the most common types of crime and incidents of public disturbance in a shopping centre?

2. Are crime and incidents of public disturbance spatially and temporally clustered in certain environments in the shopping centre?

3. Based on evidence from a 3-D model and fieldwork inspection, which are the shopping environments most in need of crime prevention intervention?

The novelty of this study is threefold. First, it suggests a conceptual framework of analyses for shopping centres drawing from environmental criminology theories. Second, it makes use of BIM-Building Information Modelling in environmental criminology for visualisation of crime and crime concentrations in shopping centres. Finally, this study advances the knowledge basis in this area by adding evidence of one of the most visited shopping centres in Stockholm, the capital of Sweden-contributing therefore to the international literature on this area.

The structure of the article is as follows. First, the shopping centre as a criminogenic place is discussed followed by a review of the potential of using 3-D visualization techniques in research and practice. The case study is framed followed by a description of the methods. Then, the nature, levels and patterns of crime and public disturbance in the 
shopping centre over time and space are presented. The chapter concludes by bringing together the evidence from a fieldwork inspection to the evaluation provided by the $3-\mathrm{D}$ visualisation as well as suggestions for improving the environment of this shopping centre using CPTED principles as a theoretical reference.

\section{Theoretical Background}

\section{Crime Theory in Risky Facilities}

Shopping centres are risky facilities (Eck, Clarke, \& Guerette, 2007; Eck \& Weisburd, 1995). These may arise from complex dynamic interactions among individuals_-offenders and controllers, mediated by the types of environments (including targets) they are exposed to. Five perspectives suggest the importance of places for understanding crime: rational choice; routine activity theory; crime pattern theory; social disorganisation theory and Crime Prevention Through Environmental Design (CPTED). Although these perspectives are mutually supportive, the first three perspectives provide different explanations for crime occurring at different places, the fourth considers the importance of context for explaining high crime areas in risky facilities and the fifth theory provides micro-environmental clues for why crime occurs in particular places.

A rational choice perspective provides the basic rationale for defining a particular place as criminogenic, since it suggests that offenders choose targets and define means to achieve their goals in a manner that can be explained (Cornish \& Clarke, 2008). Routine activity perspective seeks to explain the occurrence of crime as the confluence of several circumstances (Cohen \& Felson, 1979; Eck \& Weisburd, 1995), namely a motivated offender, then, there must be a desirable target and the target and the offender must converge in place and time. Finally, three other types of controllers - intimate handlers, guardians and place managers (Felson, 1986, 1995, 2006), must be absent or ineffective. Felson (2006) suggests that multiple actors exercise social control: handlers who control potential offenders, managers who control places, and guardians who control 
targets. In the case of youngsters at a shopping centre, handlers could be older siblings or store personnel. There could be two types of guardians in a shopping mall: formal guardians whose responsibility is to protect targets (people and property) from crime, such as police officers, security guards and store controllers, and informal guardians, including employees or other customers in a store. If the target is an individual then guardians can be family members, friends and others who are at the same place as the target. Place managers can be shopping personnel, guards, or parking lot attendants - they regulate behaviour at the locations they control. A thief may give up stealing a purse if (s)he notices that (s)he is being watched by a restaurant employee. In real life, there are overlaps between the role of handlers, guardians and place managers among those who work at a shopping mall. There may also be crime promoters-people who inadvertently, carelessly or deliberately make crime more likely to happen.

Yet, these opportunities for crime do not happen at random in time and space. They tend to follow individuals' daily rhythmic patterns of activities, and crime may just occur in some of areas/times in which a potential offender is aware of them. In crime pattern theory, this 'awareness space' refers to criminals' knowledge about the environment and its opportunities for crime, which depends on their routine activity (Brantingham \& Brantingham, 1984). Although offenders may seek out unfamiliar places and uncharted areas, most conduct their searches within the areas they become familiar with through daily activities (Santtila, Laukkanen, \& Zappalà, 2007; Wiles \& Costello, 2000), some taking place in their own neighbourhood. Thus social disorganisation theory can contribute to understanding the links between risky facilities, such as a shopping centre, in a wider geographical context. The social disorganisation theory relies on the idea that crime occurs when the mechanisms of social control are weakened (Shaw \& McKay, 1942). Crime in public places such as muggings in bus stops and burglary in parking lots in the surrounding areas of a shopping mall, for example, go hand in hand with high levels of social disorganization (Kornhauser, 1978) or low collective efficacy (Sampson, Raudenbush, \& Earls, 1997) in the neighbourhoods where a shopping mall is located. Researchers have long pointed out that 
shopping centres have problems similar to those of that a central business district (Lee, Hollinger, \& Dabney, 1999). One reason is that they may be located in criminogenic areas, places that have a disproportionate number of opportunities. Another reason is that, as with city centres, shopping malls also have alcohol selling premises, bowling and cinemas, which generate activities that reproduce problems, associated with the city centre, in particular, night life crime. One of the seminal studies with shopping centres was performed by Engstad (1975). He found that areas with shopping centres had higher rates of crime per thousand population than areas without shopping centres. However, regardless if a risky facility such as a shopping centre 'works' in fact as a crime generator or attractor (Brantingham \& Brantingham, 1995), research so far says little about whether and how the internal and external physical and social environments of these facilities influence crime and safety (Bamfield, 2012; Lindblom \& Kajalo, 2011). Note that traditionally crime generators are particular areas to which large numbers of people are attracted for reasons unrelated to any particular level of criminal motivation they might have or to any particular crime they might commit. Examples include shopping and entertainment areas while crime attractors are particular places or neighbourhoods to which strongly motivated offenders are attracted due to the known opportunities for particular types of crime. Examples might include bar districts, prostitution areas, and drug markets.

The type of building and architectural design influences what occurs in them and in their surrounding environments. The reason is that the social interactions that these environments promote (or attract) at a particular spot-are fundamental in turning these facilities from safe to unsafe (Cozens, Saville, \& Hillier, 2005; Glasson \& Cozens, 2011; Jacobs, 1961; Newman, 1972; Reynald \& Elffers, 2009). These principles underlie what is called Crime Prevention Through Environmental Design (CPTED). CPTED is defined as "the proper design and effective use of the built environment which can lead to a reduction in the fear of crime and the incidence of crime, and to an improvement in the quality of life" (Crowe, 2000 , p. 46). This implies that environments can be planned in a way that reduces the possibility of crime occurring, by stimulating surveillance, fostering territoriality and reducing areas of conflict by controlling access and improving overall perceived safety (for details, Cozens, Saville, \& Hillier, 2005; Ekblom, 2011; Jeffery, 1977; Newman, 1972; Saville, 2013). 
Most of CPTED interventions have been implemented together with other situational crime prevention techniques (Clarke, 1983) to housing developments and neighbourhoods in both urban and rural areas (Armitage, 2013; Clarke, 1989, 1992; Cozens, 2002; DeKeseredy, Donnermeyer, \& Schwartz, 2009), transportation systems (e.g. Ceccato, 2013; Loukaitou-Sideris, 2012) and parks (e.g. Iqbal \& Ceccato, 2016). Much less evidence is found in the literature about the use of CPTED to inventory safety in commercial properties and shopping (but see Clarke, 1989; Kajalo \& Lindblom, 2011; Schneider \& Kitchen, 2002). Although not free from criticisms, such as portraying individuals as passive agents or neglecting the social construction of physical space for particular groups (Ceccato, 2016a; Pain, 2000; Smith, 1987), the value of the CPTED approach resides in the attempt to gain a better understanding of the effect of micro-spaces on individuals' behaviour in a shopping centre, either as a visitor (potential target) or an offender (seeking opportunities).

\section{Crime in Shopping Centres: A Conceptual Model}

Modern shopping centres are complex environments (Fig. 8.1). The macro-scale is constituted by the overall system (the shopping centre itself and the immediate surroundings); the meso-scale can be represented by a group level of stores (a floor or set of stores or restaurants in a food court); and the micro-scale: settings in a location (e.g. an entrance, a store, the cinema) (Ceccato, 2016b). They are composed of public, semi public and private areas, sometimes with subtle boundaries between them. Drawing from CPTED principles (for a revision, Cozens et al., 2005 and Ekblom, 2011), Ceccato (2016b) proposed a conceptual framework for assessing spaces and times at a shopping centre that are criminologically relevant to crime and perceived safety. Safety in a shopping centre, taken as either as by absence of crime or fear of crime, is dependent on multi-scale environmental conditions that are at work at various levels in the building and its immediate surroundings, some of them varying over time. Based on their 


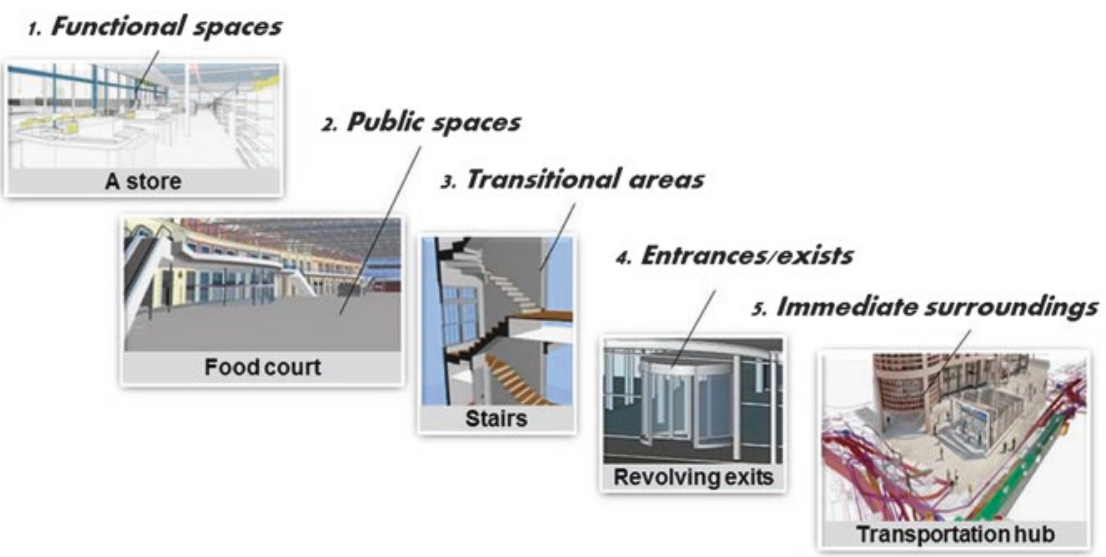

Fig. 8.1 Crime and safety in shopping centres: a conceptual model. Source: Ceccato (2016b)

capacity to generate crime relevant outcomes, Ceccato (2016b), divided the shopping premises into five parts.

Functional spaces are those spaces which have a defined function in the shopping mall, such as stores, restaurants, banks or toilets. How much they are exposed to crime depends on their location in the mall but also internal and external features such as good lighting, design and positions of doors, windows and stair cases, entrances. These features may reduce the possibility of crime occurring by stimulating surveillance, fostering territoriality and reducing areas of conflict by controlling access from outsiders (Ekblom, 1995, 2011, 2013; Jeffery, 1977; Newman, 1972; Poyser, 2004).

The vulnerability of a particular store depends on its layout, its management and the types of goods sold. Clarke and Petrossian (2013) suggest that most vulnerable parts of the store are those that carry 'hot products'. Clarke and Petrossian (2013) suggest that stores are more vulnerable to crime when they have: (1) many entrances/exits, particularly where they are accessible without passing through the checkout; (2) passageways, blind corners, and hidden alcoves; (3) restrooms or changing rooms, (4) high displays that conceal shoppers (and shoplifters) from view, (5) crowded areas around displays of high-risk items; and, (6) aisles 
that staff cannot easily survey from one end. This may explain why similar stores (same goods sold) are differently targeted by crime (Hendricks, Landsittel, Amandus, Malcan, \& Bell, 1999) and some get disproportionally large amounts of crime. There are indications that 'the law of crime concentration' (Sherman \& Weisburd, 1995; Weisburd \& Amram, 2014) may also apply to micro-scale retail crime and directly relate to these risky facilities and their surroundings.

Yet, the vulnerability of particular premises might go beyond the spatial dimension; it might be time dependent, and sometimes concentrated to particular 'time windows' (from day to seasonal ones). Bars, pubs and restaurants, for example, may become source of problems when the shopping mall closes down. Jewellery stores and retail with high valued goods (e.g., electronics) also become more vulnerable to burglary when most facilities are closed. After school hours might attract youngsters to particular settings at shopping mall, often with no guardians around (e.g., bowling, parking lots, libraries and game facilities).

Open public spaces in a shopping mall have a key role in terms of safety as they are settings of convergence at all times. Furniture and decorations in public spaces may limit visitors' capacity to exercise social control from a long distance. For instance, in a food court they may create obstacles, obstructing the field of view of clients. Open paths dividing food courts, stores and restaurants create unnecessary opportunities for thieves as they allow non-clients to have access to their premises. Previous studies suggested that small distances between tables in a food area would also make it easier for thieves to pass, grab a bag and leave (Poyner \& Webb, 1995).

Shopping centres also have transitional areas, such as corridors, stairs and paths. Length and width, location, types of materials, enclosure and design, all affect how safe these transitional areas are. Corridors often have obstacles placed in locations that might offer criminals opportunities to commit a crime and then hide (Newman, 1972). These environments may differ in terms of 'properties, features and content' that directly impact on overall safety (see Ekblom 2011, for details). Examples of these obstacles can be temporary shops, permanent pillars or furniture, blocking the view of transients. They can themselves be a target of crime as people might steal goods. Demonstration stalls at corners and in public spaces in the shopping centre help visitors to get to know new products 
but also to become distracted, and as a consequence, becoming themselves an easier target for thieves. Corridors might be straight and in peak visiting hours, they can be a source of irritation as well as places for bag snatching and pickpocketing. Moreover, if anyone is allowed in the area, this might create a sense that nobody is in control. This feature is particular important for places such as entrances/exits.

The entrances carry the identity of the shopping centre. They can be of many types, for pedestrians or for cars, giving access to the parking lot. In any case, well-functioning entrances allow the flow of people (or cars), both under normal and emergency conditions. Using semi-transparent materials and glass in the construction of entrances allows good sunlight illumination and may affect natural surveillance. The entrances are also the connection of the centres with the rest of the city. The number of entrances varies with the size of the shopping centre. More entrances increase the flow of passengers and according to routine activity theory (Cohen \& Felson, 1979), crime opportunities. More entrances in problematic neighbourhoods may mean more crime.

A shopping centre's immediate surroundings are also an important criminogenic factor for what happens inside the mall. High crime areas tend to affect victimization at shopping centres and perhaps vice-versa (see 'crime radiators' and 'crime absorbers', by Bowers (2014)). Bowers (2014) suggests that there is a positive relationship between internal and external crime in an area. Two different mechanisms might explain such a relationship, one that risky facilities act like crime 'radiators' and transmit risk to the external locale, while the other is that they are crime 'absorbers' - they absorb risk from the external locale. Public transportation links to a shopping mall are essential for bringing customers but bus stations and underground stations are themselves crime attractors, and they allow an easy escape for criminals (Ceccato, 2013; Ceccato, Cats, \& Wang, 2015). Failed security systems in parking lots bring in individuals that would not have the right to be in the premises, including thieves. The impact of CCTV cameras in reducing crime in parking lots has long been confirmed in the literature, at least for property crime (Welsh \& Farrington, 2009). Inner city shopping centres may be extra vulnerable to crime spill-over from mixed land use, with bars and restaurants. 


\section{Visualisation of Crime Incidents in 3-D and BIM: Building Information Model}

The studies by Rengert and colleagues in the USA from late 1990s and mid-2000s are seminal in the analysis of crimes in buildings. These prototypes were later tested and described in Rengert and Ratcliffe (2005) on the 3 - $\mathrm{D}$ visualisation of inmate violence against correctional staff. Authors selected two county prisons in the King County, Washington because they thought they had valuable design characteristics that provided a unique opportunity to study different spatial arrangements of prisons. One location was a traditionally spread-out site with considerable horizontal expansion while the second was a high rise installation. Rengert and Ratcliffe (2005) assumed that by studying different floor plans and supervision models, it would help them to translate their findings to other prisons across the country. Authors summarised the available technological paths at that time to build a 3-D visualization model for crime events as following:

Each floor plan was registered as an 'area'. Each room on a floor, each sightline in a hallway and each exit from an elevator or stairway are assigned a 'location' within this area. Once each unique location was identified, the user was capable of assigning incidents to each location. In this simple approach, incidents were plotted in the centre of each location with the symbol designating the number of incidents that occurred in that location over a designated time period. (p. 22)

Later on, they developed an advanced GIS approach to visualise in more detail and with more accuracy the crime location (e.g., no longer at the middle of the room). Yet, while the capacity to visualise incidents onto a digital map provides a wealth of possibilities, Rengert and Ratcliffe (2005) concluded that it also created some barriers to effective analysis, such as increased software and training costs and problems with the identification of repeat victimization. Moreover, they did not explore the temporal dimension of crime incidents across the 3-dimensional space. Taking the previous work by Rengert and colleagues, this study takes a 
step forward by testing a prototype with new visualisation tools (BIM) and explores the temporal dimensions of crime in space in a shopping centre.

\section{The BIM Approach}

The term BIM, which comes from Building Information Modelling, can be defined as "a modelling technology and associated set of processes to produce, communicate, and analyse building models" (Eastman, Teicholz, Sacks, \& Liston, 2011, p. 16). The notion of 'building models' denotes digital representations of building components containing geometry, functional and behavioural attributes and parametric rules (Eastman et al., 2011). However, BIM as a term can be misleading. As suggested by Bisio (2016), BIM is not just about buildings, it is a process that enables efficient and quality design, construction and operation of a structure such as a building (e.g. a shopping centre), a bridge or highway. One of the most appreciated capabilities provided by BIM is high-end 3-D visualization. Despite great potentials, visualization capabilities offered by BIM are limited to a number of areas (Becerik-Gerber \& Rice, 2010). No previous research has tested the use of BIM for visualizing and analysing criminal occurrences inside buildings, such as a shopping centre.

\section{The Case Study}

Sweden has about 300 shopping centres today, twice as many as the country had 15 years ago (Grip, 2012; Sorbring, 2012). The shopping centre used as the study area is one of Stockholm's largest shopping centres with 19 million visitors per year, and has the longest opening hours (10-21 hours, over 180 shops), a large number of restaurants including a food court and other leisure activities such a movie theatre, a bowling alley, a hotel and a go-kart track. This shopping centre includes stores from the most important Swedish chains. The mall is frequented both weekdays and weekends, with around 60,000 and 45,000 visitors per 
day, on average 350,000 a week. There is also a large library and a hotel. The mall is located adjacent to a metro line (18 minutes from Stockholm central station) and a large bus station with several bus routes to other parts of the city. The shopping centre is located close to the largest Information and Communication Technology cluster in Europe and one of the biggest in the world (CITYCON, 2016). Equally important is to mention that the shopping mall is located near several areas in the Stockholm region with relatively high crime levels (BRA, 2016).

The mall is formed with a main entrance in the middle of the building. There are two floors, a main floor where most of the activities are available and an upper floor where some shops, a restaurant and cinema are sited. In the middle of the building is the shopping heart, the food court with some 20 restaurants. There are eight entrances of different sizes. What is also relevant from a criminogenic perspective is that in the middle of the aisles too some activities are situated, including telemarketers, sweet stores and cafes. From the mall student housing located on top of the main building can be reached (CITYCON, 2016).

\section{Data}

The empirical materials used for this study were:

1. reports of occurrences of crime over a period of 17 months (from January 2015 to May 2016) in PDF format. This dataset was used because police records cover just a minor portion of total incidents, for shoplifting is only 2 percent of the total, for example (Swedish Trade Federation, 2015). The data is gathered by the company in charge of security services in the mall. There are different ways of reporting crime and incidents of crime and disorder. The most common way if a crime happens or is ongoing is that personnel press a button ('panik-knapp', 'bråk-alarm'), so the security company is immediately informed and can intervene if the incident is still ongoing, or report it after the event. Incidents other than crime are also recorded in the same database. The security company does not cover the parking 
lots, and incidents that take place there are not included in this dataset. Supermarkets are open from 8:00 to 21:30 while bars are open from 10:00 to 24:00. The majority stores open between 10:00 and 21:00 hours.

2. Number of visitors by trading hours in 2014 provided by shopping mall.

3. 14 plan drawings of different floor levels of the retail facility including names and codes of the constituent spaces, tenant businesses as well as horizontal and vertical dimensions of spaces in PDF format.

4. Data collected through fieldwork inspection performed in a series of visits to the shopping centre in particular environments most targeted by crime and incidents of public disturbance.

\section{Methods}

In order to obtain a better understanding of the nature of crime concentration in space and time in a shopping centre, a 3-D visualisation using BIM was combined with fieldwork inspection.

\section{Creation of the Object-Oriented Semantic Model of the Shopping Centre}

An object-oriented model of the entire building was constructed based on the drawings using a proprietary BIM-authoring software application (Autodesk Revit 2013 ${ }^{1}$ ). Next, underlying plan drawings were used for creating a three-dimensional model of the building at a relatively low level of detail. The levels of detail of the model were based on three level scales: the macro-scale: the overall system (the shopping centre); the meso-scale (a floor); and the micro-scale: settings in a location (e.g. food court, an entrance). Each floor was considered a separate layer connected by limited access corridors or ways (elevators and stairs) that could also be visualised together and be the basis for analysis. Then, the next step was to populate this model with crime data. Through an iterative process, 
both the model and XML reports were synchronised to reflect the total number of events per room. First, a standardized list of crime types was used for interpreting the descriptive texts through reports. Then, based on official crime codes (BRA, 2012), several filters with key words associated with each offence were created (e.g. 'snatt' was meant to look for cases of 'snatteri', shoplifting). After several trials using different filters, 90 percent of crime occurrences and incidents of public disturbance were mapped in the model.

\section{Visualisation of Space-Time Patterns of Crime with BIM Model}

Cylinders were used to represent the volume or rates of crime by location in each store. In order to visualise crime by location and over time, a tool was programmed allowing three 3-D mapping modes: Choropleth 3-D map-The size of the cylinder corresponds to the absolute number of crimes per type and location. This feature is useful to compare particular sections of data by crime type, for instance, peak hours versus off-peak hours. Stacked cylinder map-The size of cylinder is standardized by 100 percent (total crime by each individual location in space) and is split by the proportion of each crime incident (absolute numbers) for each crime location. Scaled map-The most important advantage of this mode is that it indicates a unique specialization of crime incidents by location, for instance, violence dominates security guard calls for service in bar A while in shoplifting and thefts dominate calls in supermarket B. In all modes, the tool makes it possible to filter crime incidents by time slices, for instance, to visually check sections of the data by day or hours of the day.

\section{Inspection of the Shopping Environment}

In order to assess the environments where crime is mostly concentrated, a systematic and detailed 'inspection' of the crime locations in the shopping centre (including photographic documentation), as well as a check 
on the surrounding area of the shopping centre were conducted in JuneAugust 2016. Using CPTED principles a template was developed to check the conditions at these locations: illumination, dark corners, hiding places, clear field of view, transparent materials, presence of objects/ barriers, level of maintenance, formal and informal social control, visibility, target hardening features, social environment (people gathering outside, blocking entrance, drinking, noise, beggars sitting outside, litter) and land use of immediate environment (transport nodes, ATM machines, bars). Results from the visualisation combined with the fieldwork inspection provided the basis for making suggestions for improvement of the most targeted settings and/or areas in the shopping centre as presented in the following sections.

\section{Results}

\section{The Most Common Crime and Safety Related Incidents in the Shopping Centre}

Out of 5768 (11.2 cases per day about 1 incident per open hour) from January 2014 to May 2015, 68 percent of incidents are acts of public disturbance and vandalism (Fig. 8.2). This overwhelming majority of records of minor incidents is typical of other public places in Stockholm (see, for example Ceccato, 2013). Acts of vandalism include graffiti on walls or floors, as well as damage to objects. They are rarely inside the shopping mall, and more often in the immediate surroundings. Note that incidents of public disturbance are not crimes and therefore are not part of police records, resulting in a dataset that is dominated by thefts and acts of vandalism and to a less extent violence. Regardless of whether they are offences or not, the overwhelming majority of these minor incidents are bound to have an impact on visitors' perception of risk of crime and ultimately on their perceived safety.

There are also violent acts and/or threats, which compose 16 percent of incidents. Conflicts among young people who spend time after school at the library or other shopping premises (fast food restaurants) are common; 


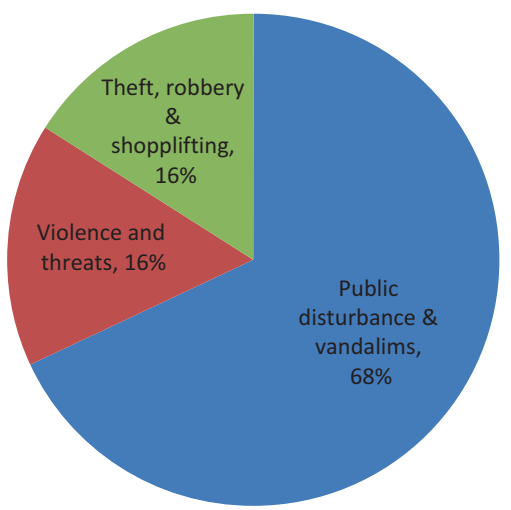

Fig. 8.2 The most common types of incidents recorded in the shopping centre, Jan 2014-May 2015, N = 5768 incidents. Data source: Security company, 2016

as well as cases in which personnel feel threatened by customers' behaviour. Theft, robbery and shoplifting with 16 percent of incidents were common in jewellery stores, electronic/mobile phone stores, clothing stores as well as supermarkets. A new study in Sweden shows that shoplifting can be as high as 8.1 billion dollars per year (Swedish Trade Federation, 2015) and crimes of these type are also common elsewhere (Clarke \& Petrossian, 2013; Hendricks et al., 1999; Poyner \& Webb, 1995).

Within each crime group there are major variations of types of behaviour, for instance, among cases of property crimes, there are records of minor crimes, such as attempts of shoplifting to major burglary followed by theft with use of weapons, cars and explosives (e.g. against jewellery and electronic stores). Violence and threats include physical violence (fights, including sexual assault) as well as verbal ones, threats against personnel or other customers but also sexual harassment. Table 8.1 illustrated common incidents recorded by the security company in this shopping centre. 
Table 8.1 Typical examples of crime and incidents of public disorder from the database

\begin{tabular}{|c|c|}
\hline Events & Typical examples \\
\hline Violence \& threats & $\begin{array}{l}\text { Two children fought with each other and parents got } \\
\text { involved too } \\
\text { Non-Swedish speaking customer wants to change a } \\
\text { product, the customer is now upset and making threats. } \\
\text { Security guard is assisting store personnel } \\
\text { Staff at mobile store calls and says that a person is } \\
\text { threatening them }\end{array}$ \\
\hline $\begin{array}{l}\text { Theft, robbery \& } \\
\text { shoplifting }\end{array}$ & $\begin{array}{l}\text { Jewellery call for help. Security guard announced a theft } \\
\text { of three watches } \\
\text { Store called on suspected shoplifters at the store } \\
\text { A custom's purse was stolen in main public corridor } \\
\text { A bag was stolen close to restaurant X in the food court }\end{array}$ \\
\hline $\begin{array}{l}\text { Public disturbance } \\
\& \text { vandalism }\end{array}$ & $\begin{array}{l}\text { Staff at a restaurant call for help as they have people } \\
\text { vandalizing their soda automat } \\
\text { Security guard is called because there is an intoxicated } \\
\text { man disturbing other shopping visitors in the food court } \\
\text { A large group of young people were screaming and } \\
\text { raging in the library } \\
\text { Three women are undressing and washing their clothes in } \\
\text { the sink at the restaurant toilets. Security guards went } \\
\text { there and talked to them }\end{array}$ \\
\hline
\end{tabular}

\section{Temporal and Spatial Patterns of Crime Incidents of Public Disturbance}

Figure 8.3 shows that most crimes and incidents of public disturbance in the mall happen in the evenings, but a peak is also observable in the afternoon hours. Although there are variations between crime types, for property crimes, for instance, most crimes happen around 14:00, but there are also peaks between 18:00 and 21:00. Violence, vandalism and problems of public disorder peak between 18:00-20:00 hours. Interestingly, a minor peak for property crimes has been recorded in the morning, just after opening hours. This peak comprises records of burglary (often against electronic stores, jewellery stores), crimes that often happen during the night are only discovered when the mall opens (note that 'burglary' is included in the category 'thefts and robberies' in all Figures of 

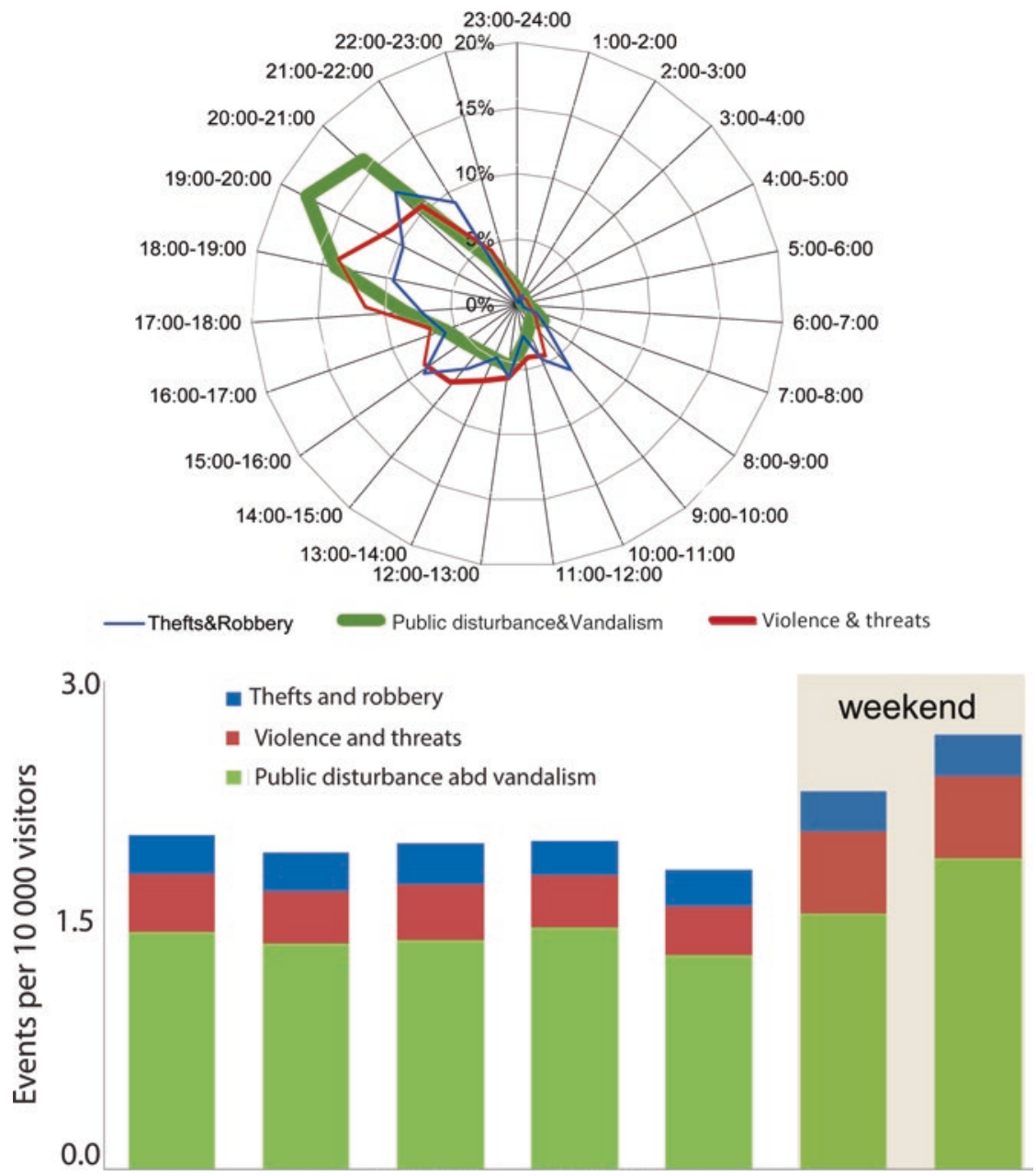

Fig. 8.3 When do most incidents happen? Hourly, daily and monthly patterns, 2014. Note that daily and monthly patterns are events per 10000 visitors. Data source: Security company, 2015-2016 and shopping mall, 2014 


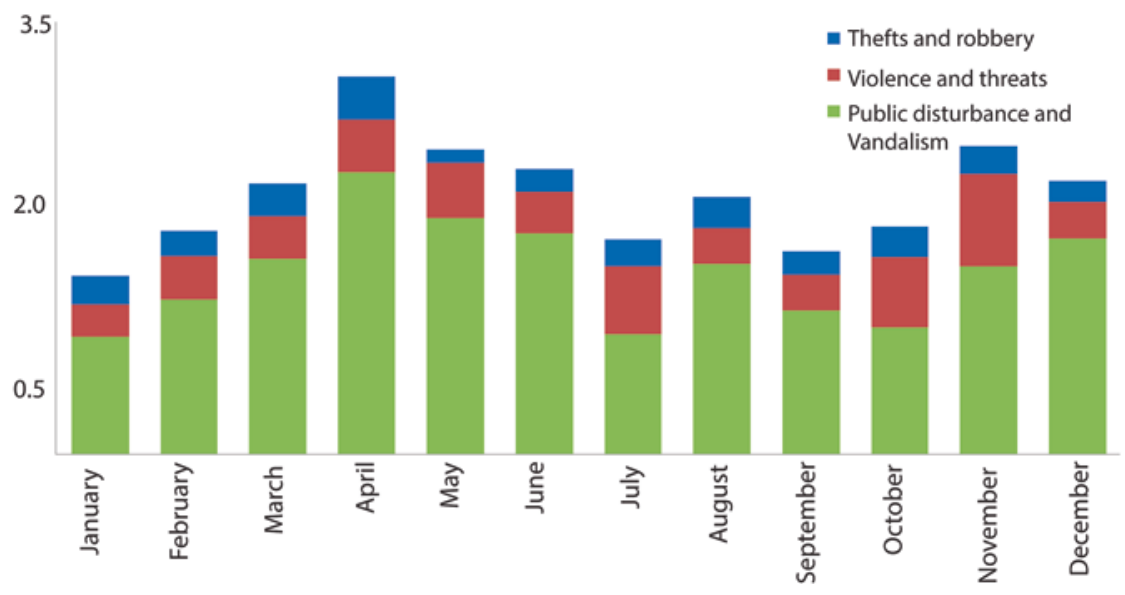

Fig 8.3 (continued)

this chapter). This shopping centre has relatively long opening hours (stores 10:00-21:00 hours, bars, up to 24:00 hours). Yet, crime records decrease drastically after 22:00.

The peak after 18:00 for all crimes and incidents of public disturbance is associated to people's patterns of routine activity (Cohen \& Felson, 1979; Felson, 2002), namely it is when customers go shopping, run errands after work, engage in leisure activities and eat, or just spend time with friends after school hours. In order to check daily variations, frequency of violence was standardised by total visitors per day. Note that this shopping centre had an average of 358,000 visitors a week (trading hours) in 2014. Figure 8.3 shows that crime rates are higher over the weekend. Yet, it is important to notice that they are higher not because there are more crimes but because fewer visitors go there over the weekend (crime frequency is fairly constant over the week). Compared with shoplifting and other property crimes, such as burglary, violence and acts of public disorder tend to be slightly higher on Saturdays and Sundays than weekdays. The data also show seasonal variations. Spring (particularly April) and autumn (November) show both high number of crimes as well 
as rates. However, summer (July) shows a slightly larger rates of violence, which also appears in the autumn (October and November). Now we turn our discussion to the spatial patterns of crime in a shopping centre.

The crime geography in the shopping centre provides evidence of the law of crime concentration at the micro-scale level (Eck \& Weisburd, 1995; Weisburd \& Amram, 2014; Weisburd, Morris, \& Groff, 2009). As much as 64 percent of all incidents happen in 10 percent of meso and micro-places in the shopping centre.

\section{Visualising Crime in Shopping Centres Using BIM Diagrams}

Figure 8.4a shows the geography of crime per store location in the BIM diagrams. The rank is topped by the food court (mostly public disorder) followed by two fast food restaurants, then by two entrances and not far behind, two main corridors linking the stores (note that these corridors also contain temporary stalls). This rank depends on crime type. For property crimes, for example, shoplifting in supermarkets and clothing stores (large Swedish chains) are the most targeted places. It is unclear how much of this shoplifting is associated with self-service check-out in the Swedish case (but see Taylor, 2016; for evidence from elsewhere).

Alcohol outlet stores (Systembolaget, 2013) ${ }^{2}$ in this shopping centre are commonly targeted. Although armed robberies with heavy weapons against electronic stores and jewellery shops constitute few cases in a year, they are the ones that visitors notice the most. These findings fit the picture portrayed by the local media about this shopping mall. According to Johansson (2016) the majority of the press articles recently published about crime in this shopping mall were about robbery of all types, with and without use of weapons. Threats and assault against a person or fights populated cases of violence that account for 17 percent of all records. Facilities and stores located close to entrances tended to experience more safety problems than the ones far from the entrances/exits of the shopping centre. Note Johansson (2016) in her exploratory study with a small sample of respondents found that entrances and the parking garage were places where visitors felt most unsafe. Notably, these are also places where 
a

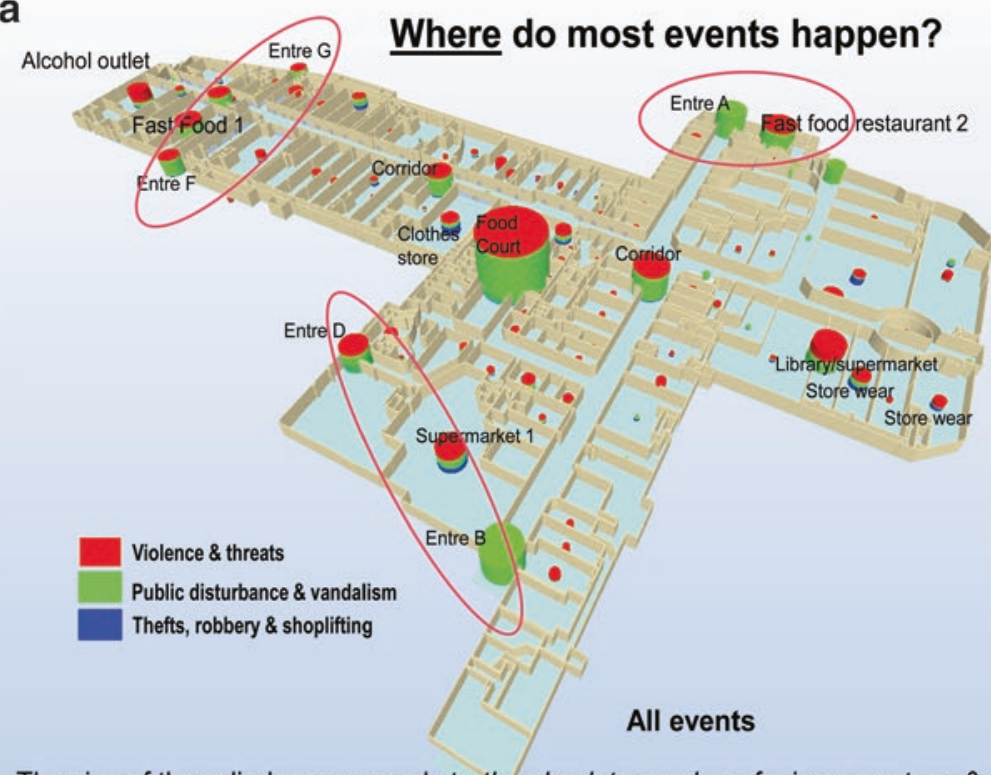

The size of the cylinder correponds to the absolute number of crimes per type \& location

b

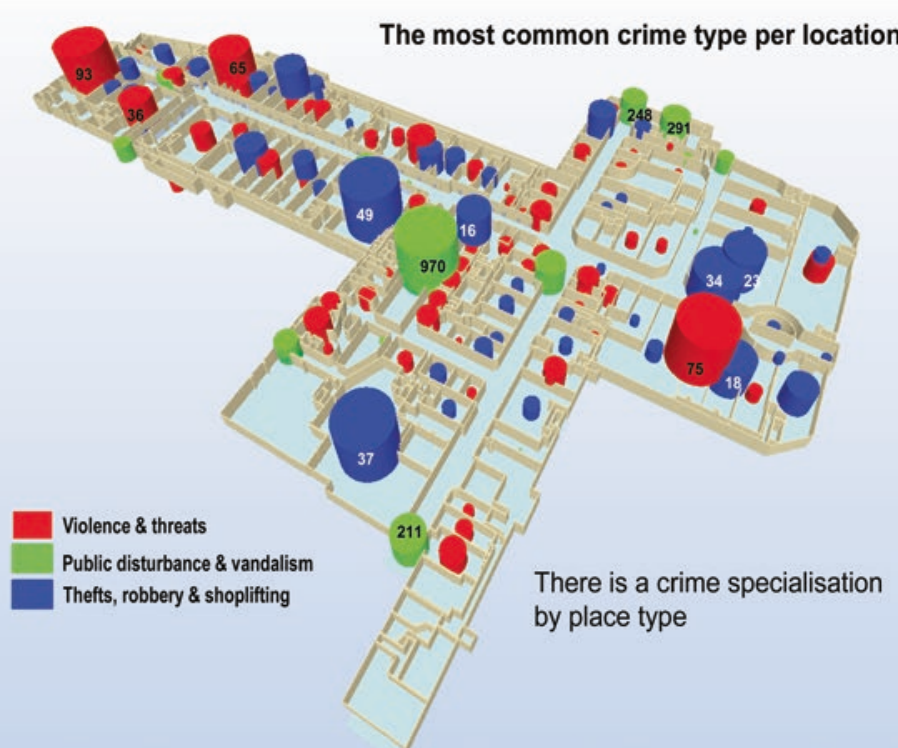

The size of the cylinder correponds to the relative number of crimes per type \& location

Fig. 8.4 (a) Crime by type and location and (b) the most dominant crime type per store and (c) crime in peak hours 


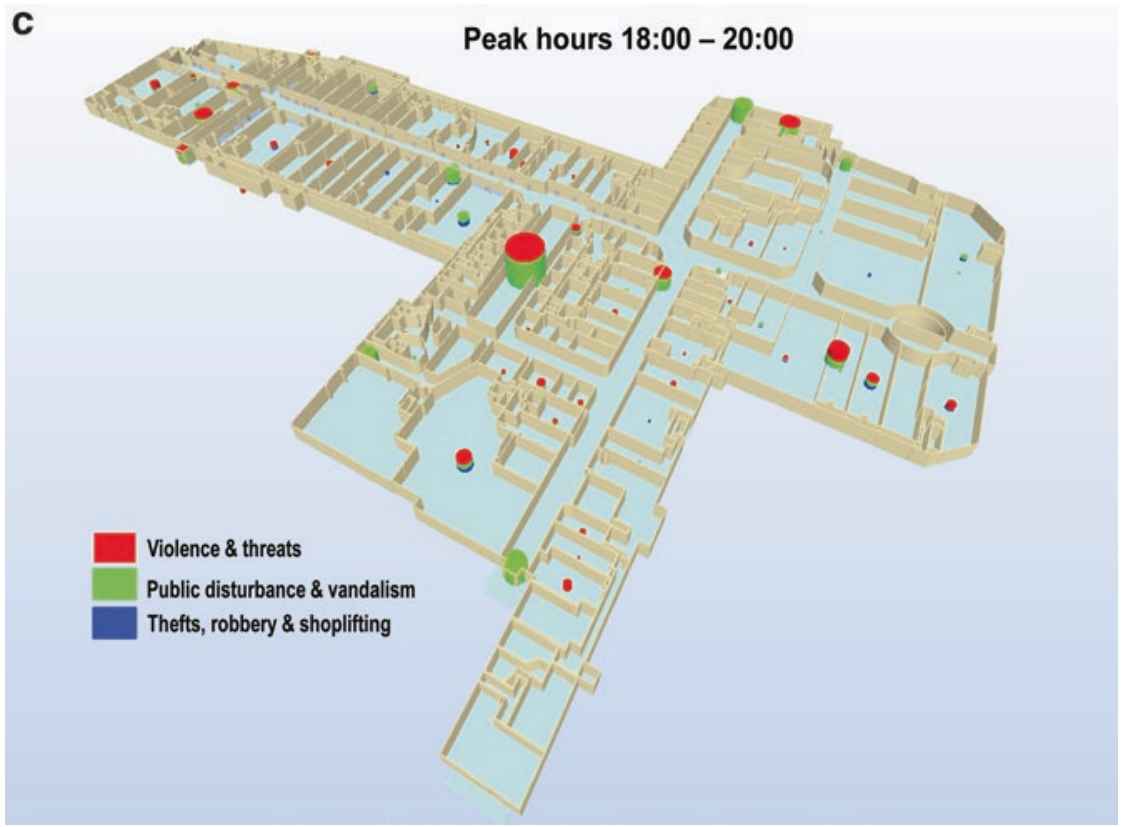

Fig. 8.4 (continued)

visitors have responded they are relatively dissatisfied with the comfort level. It has been observed that there is a clear crime specialisation per location and crime type Fig. 8.4b. Food courts tend to have more problems with public disorder while stores experience more property crimes; entertainment centres and restaurants experience problems with threats, assault and other violence related issues. Similar visual snapshots over the shopping mall were created to illustrate crime peak and off peak hours for all types of offences by hour of the day, weekdays and by month (example shown in Fig. 8.4c).

\section{The Shopping Environment Most in Need of Intervention}

Table 8.2 exemplifies a set of places in the shopping centre that are most in need of intervention. This analysis was based on intensive fieldwork 
Table 8.2 Examples of places most in need of intervention following CPTED principles

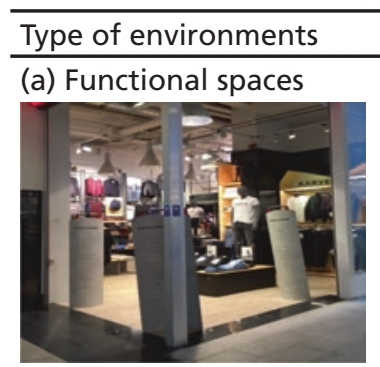

(b) Public spaces
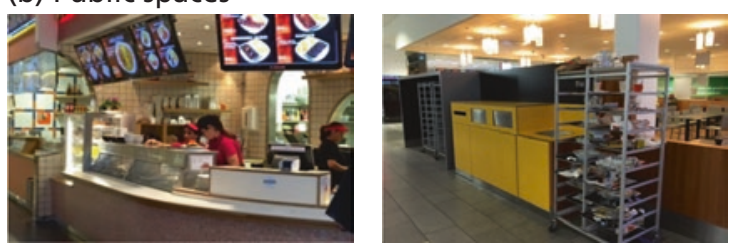

(c) Transitional areas
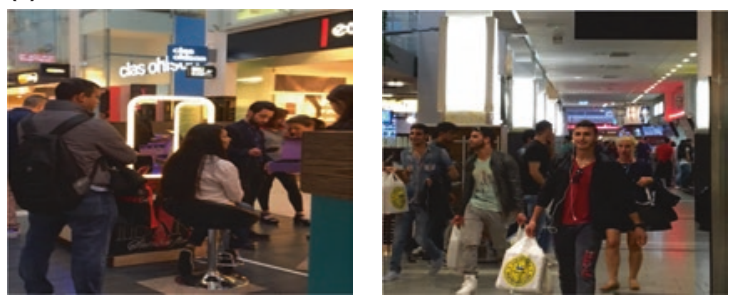

(d) Entrances/Exits
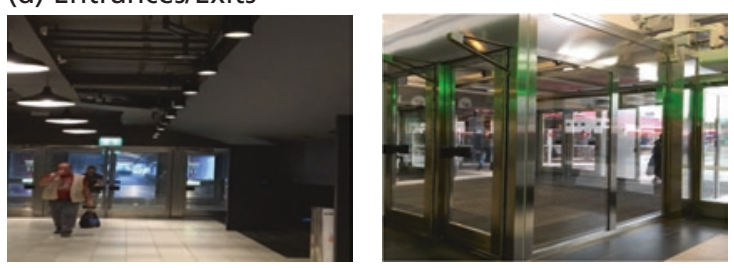

(e) Immediate surroundings
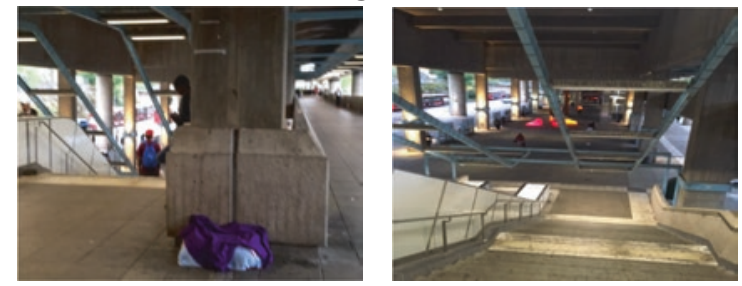

Main safety issues

- permeable spaces

- poor territoriality markers

- lack of access control

- easy escape

- unintended use of premises

- poor natural surveillance (blocked view, hidden spots)

- access control \& permeable spaces

- image/poor management

- tight corridors

- disruption by physical barriers

- poor natural surveillance-stalls affect visibility

- products easy to steal

- illumination

- easy escape

- lack of access control
- illumination

- easy escape

- alcohol drug use

- rowdy youngsters

- unintended use of premises

- desolate at certain times 
using CPTED principles and maps of hot spots of crime over time and across the shopping groups discussed in the previous section. Instead of describing all potential problems with the design of the environment and management of the shopping groups, the next paragraphs reveal some examples of each type of environment, namely, functional spaces, public spaces, transitional areas, exits/entrances and immediate surroundings following the conceptual framework suggested in the beginning of this chapter (Fig. 8.1).

Among functional spaces, the layout of selected stores is particularly problematic in this shopping centre. A number of stores targeted by crime have their door layout in common. They allow non-customers to pass-through the store which makes them more vulnerable to thieves. Some supermarkets share the same problem of permeability of boundaries between public and private areas. The entrance to the stock of goods is, in one supermarket, located in the middle of the store, giving free access when open. A set of establishments (e.g., money exchange, jewellery, electronic) should consider relocating to other sites within the shopping mall that are more secluded, yet well-guarded. Armed robbery in jewellery stores happens often early in the morning (09:00-11:00) with use of heavy weapons, cars and even motorcycles. Moreover, security guards should be alert at particular sites, at particular times. Security officers could patrol on motorised vehicles to respond quickly if on call (targeted areas) and to maximise visibility on shopping grounds.

Another example of places that need intervention among functional spaces is the library and the toilets. The library is often linked to conflicts among users (especially youngsters after school hours) and between personnel and users. Clear rules about what can be done in the library should be available at the entrance. Training of library personnel to deal with conflicts between users should be considered. With regard to toilets, unattended toilets are used for other purposes for temporary visitors, including the homeless. Isolation of toilets (often located in isolated spots) makes them possible sites for anything from robbery to sexual assault. Having personnel more often in toilets (maintenance or housekeeping personnel) would be desirable if relocation is not viable. In 
summary, among the CPTED principles, the main safety challenges in functional spaces involve problems of permeability (e.g. easy escape), poor territoriality markers and lack of access control (e.g. unintended use of premises) (Table 8.2a).

The food court is an example of a public space with a set of safety issues. The presence of multiple barriers affects visibility (breaks field of view) and negatively impacts on natural surveillance. Another visibility problem is the presence of objects, stairs, food stands, and an excessive amount of furniture, which provides corners to hide and allows anonymity/distractions that offenders need to act. Moreover, issues of permeability within sections of food court facilitate pickpocketing, bag snatching and conflicts between visitors in busy times. More formal control in the form of security guards are desirable at peak times (18:00-21:00) in the food court as well as CCTV cameras. In order to maximise guardianship, this practice should be encouraged and integrated as part of the activities that are carried out in the shopping centre, especially during hours of least activity within the mall. Overall, public spaces in this shopping centre show a number of challenges according to CPTED principles. They have features that hinder natural surveillance (objects and poor design that block the view or generate hidden spots), weaken territoriality (several spots that are permeable) and damage the image of the place as a safe environment (e.g. limited maintenance) (Table 8.2b).

Equally important are the transitional areas. Stores and stalls along the main corridor are extra vulnerable places; they make visitors vulnerable to crime, for instance, pickpocketing. The stands themselves are more at risk as products are openly exposed along the corridor. They also disrupt the landscape, making it more difficult to see what is happening. Visitors also complained about feeling unsafe along the corridor when it is too crowded. These corridors are perceived as tight and unsafe because of volume of visitors and the presence of temporary stores. According to CPTED principles, tight corridors associated with intense flow of visitors impose clear security restrictions (Table 8.2c). Stalls along corridors disrupt natural surveillance, the boundaries between public and private become blurred (territoriality), making it easy to steal products on 
display or from transients. It is understandable that shopping centres have requirements other than security, such as the need to maximise use and income from floor space. Therefore, it is extra important to promote good design to achieve both security and other goals.

At entrances/exists, interior and exterior lighting in the shopping centre and other external areas towards the bus station and underground station has to be constantly inspected. According to CPTED principles, entrances and immediate surroundings impose a number of challenges that go beyond design and maintenance of the physical environment. Having welcoming hosts at those areas may improve social control and avoid gathering of people at the entrance and blockage of the entrance (Table 8.2d, e).

External entrances and immediate surroundings are targeted by a number of incidents that are not always crime but affect perceived safety of personnel and visitors of the shopping centre. A range of programs and best practices to tackle these issues requires effort from multiple actors (shopping centre, municipality, those responsible for the transportation hub located just outside the mall) in collaborative schemes that are tailored for that particular community. These more comprehensive programs do not obviously fall into the traditional framework of CPTED, yet, they embed the need for expanding the role of CPTED to include more holistic solutions to safety-those that consider safety as an individual right.

\section{Conclusions}

This study illustrated the nature of crime in space and time in a shopping centre in Stockholm, the capital of Sweden. Drawing from environmental criminology theory and in particular, principles of Crime Prevention Through Environmental Design (CPTED), this analysis is carried out at three scales: the macro-scale: the overall system; the meso-scale: in a group level of stores; and the micro-scale: settings in a location. The methodology applied makes use of three-dimensional visualisation using 
BIM (Building information modelling) to detect places where crime concentrates. With these diagnostics in hand, a fieldwork inspection was performed to detect the most problematic areas in functional spaces, public spaces, transitional areas, entrances/exits and immediate surroundings. The chapter concludes by discussing the potential of using this methodology to identify the types of environments that are in need of extra attention to improve safety.

Findings show that 68 per cent of the incidents recorded in the shopping centre constitute problems of public disturbance and vandalism, the remainder being 16 percent of violence and 16 per cent of property crimes. Crime is not distributed randomly either in time or space. Results show peak and off peak hours for all types of crimes, but the most vulnerable time window is between 18:00 and 20:00 hours. Despite variations by crime type, weekends tend to show higher crime rates than weekends, with particular peaks in the spring and later autumn.

Most problems happen in relatively few types of facilities. Findings also illustrate the potentiality of using BIM-Building Information Modelling - in environmental criminology for visualisation of crime and crime concentrations in micro-environments in shopping centres, in particular when multi-storey buildings are the study area. The 3-D visualisation has shown evidence that crime not only concentrates in space; it shows that a disproportionally high amount of crime takes place in a limited set of places - a finding that helps corroborate much of the previous research of crime concentration. Note that 64 percent of all incidents happen in 10 percent of micro-places in the shopping centre, in particular food court followed by two fast food restaurants, then by two entrances and not far behind, two main corridors. These maps also allow showing how different environments in the shopping are crime specialised (when a type of crime dominates in the facility) over time, which illustrates the potentiality of the tool for crime prevention. The time and space visualisation can be better demonstrated if the BIM diagrams include standardisation by space-use categories, for instance, by shading the map itself or the cylinders. Future development of the BIM visualisation should include automatically generated statistical indicators, with 
descriptive by time and space but also global and local measures of spatial association.

With the fieldwork inspection it was possible to obtain clues about why similar places ended up having different levels of crime. A list of environments most in need of intervention was suggested using the conceptual framework suggested in this study. Although the inspection of the shopping mall (as it was performed in this study) is not conclusive as to whether the environment is the main cause for crime, this research provides some guidance to how their location in the shopping mall and their design make them more crime targeted than others. This limitation calls for caution when drawing conclusions about the causality between crime occurrence and shopping environment. Future research should devote time to test, in a more controlled manner, the potential effect of changes in the environment over time.

This study has two important theoretical contributions related to CPTED framework. First, it shows that in conjunction with BIM diagrams, CPTED principles can provide a solid theoretical basis for inspecting safety conditions of a shopping centre. Although not all principles of CPTED are equally important to assess safety in these facilities, they support the understanding of the nature of the relationship between design, use of space, crime and safety. A way forward to improve this analytical model is to further explore the use of the notions of properties, features and content in CPTED, as suggested by Ekblom (2011). The impact of property of 'enclosure' (that separates off part of the environment from the rest) or 'the feature of design' (whether via materials, structure and form) could be further explored when planning for internal and external environments of a shopping centre.

Second, if CPTED principles are to be applied to large retail facilities, such as a shopping centre, then more attention should be given to the role of urban context in CPTED as theoretical framework. This study indicates the advantages of considering the parts of shopping facilities, their specific criminogenic characteristics and to some of extent, the interactions between these conditions and those that define the place in which the facility is embedded. This is however not theoretically sufficient. 
Whether shopping malls concentrate crime or not, we claim that the complexity of safety in these facilities can only be fully understood if neighbourhood and city contexts are integrated in the CPTED framework.

There is a need to better tackle both in theory and practice the concept of territoriality of public spaces in retail. Shopping malls are privately owned, yet they are public places. As in the Swedish case shows, there has been misuse of entrances as well as misappropriation of internal public spaces (such as toilets and stairs). Some groups, just by their presence at entrance, for instance, can be a source of fear to others. Yet, a shopping centre as a public space means that access to it is a lawful right; everybody has the right to spend time and feel safe there. However, the right of an individual to access and spend time there affects everybody's right to feel safe. This ambiguity in ownership, responsibility and use of the shopping environment plays negatively against those who are responsible for their quality, which at the end impact on customers' safe.

Shopping centre environments should be safe and pleasant for all. Good planning and well considered practices can increase the odds that major retail environments, such as shopping centres, are safe for both visitors and personnel. It is fundamental that shopping centres are properly designed to promote the effective use of the environment and contribute to the safety of those visiting and working in the premises. However, it is important to acknowledge that shopping centres have other goals than security (such as the need to maximise use and income from floor space), therefore a need of good design to achieve security and basic commercial goals is fundamental. Despite the limitations, this study is a contribution to the knowledge on how crime varies over time and space in a shopping centre and how this information combined with a detailed knowledge of these environments can help to promote better safety in these facilities.

Acknowledgements We thank the reviewers of this chapter as well as comments provided by the audience of the seminar "Retail crime: International evidence and prevention" that took place in Stockholm, Sweden, 15th September 2016. 


\section{Notes}

1. http://www.autodesk.eu/

2. Systembolaget is a government-owned chain of liquor stores in Sweden and it is the only retail store allowed to sell alcoholic beverages that contain more than 3.5 percent alcohol by volume. To buy alcoholic beverages at Systembolaget one has to be 20 years of age or older.

\section{References}

Armitage, R. (2013). Crime Prevention Through Housing Design: Policy and Practice. Basingstoke: Palgrave.

Bamfield, J. (2004). Shrinkage, Shoplifting and the Cost of Retail Crime in Europe: A Cross-Sectional Analysis of Major Retailers in 16 European Countries. International Journal of Retail \& Distribution Management, 32(5), 235-241.

Bamfield, J. (2012). Shopping and Crime. Basingstoke: Palgrave.

Becerik-Gerber, B., \& Rice, S. (2010). The Perceived Value of Building Information Modeling in the U.S. Building Industry. Electronic Journal of Information Technology in Construction, 15, 185-201.

Bisio, R. (2016). Applying BIM to Design of Sites and Structures. Retrieved April 12, 2017, from http://www.smartdatacollective.com/ron-bisio/426210/ applying-bim-design-sites-and-structures

Bowers, K. (2014). Risky Facilities: Crime Radiators or Crime Absorbers? A Comparison of Internal and External Levels of Theft. Journal of Quantitative Criminology, 30(3), 389-414.

BRÅ, Brottsförebyggande rådet-The Swedish National Council for Crime Prevention. (2012). Kodning av brott anvisningar och regler. Retrieved April 8, 2017, from https://www.bra.se/

BRÅ, Brottsförebyggande rådet-The Swedish National Council for Crime Prevention. (2016). Utsatta omräden-Stockholm. Retrieved May 4, 2017, from http://www.bra.se/bra/brott-och-statistik/statistik/utsatta-omraden/ stockholm.html

Brantingham, P., \& Brantingham, P. (1984). Patterns in Crime. New York: Macmillan.

Brantingham, P., \& Brantingham, P. (1995). Criminality of Place: Crime Generators and Crime Attractors. European Journal on Criminal Policy and Research, 3(3), 1-26. 
Ceccato, V. (2013). Moving Safely: Crime and Perceived Safety in Stockholm's Subway Stations. Plymouth: Lexington.

Ceccato, V. (2016a). Har Stadsmiljön Betydelse för Säkerheten? CPTEDmetodens Möjlighter och Utmaningar. In D. N. T. H. K. Olsson (Ed.), Urbanismer: Dagens Stadsbyggande i Retorik och Praktik (pp. 99-120). Stockholm: Nordic Academic Press.

Ceccato, V. (2016b). Visualisation of 3-Dimensional Hot Spots of Crime in Shopping Centers. Paper presented at the Retail Crime: International Evidence and Prevention, Stockholm.

Ceccato, V., Cats, O., \& Wang, Q. (2015). The Geography of Pickpocketing at Bus Stops: An Analysis of Grid Cells. In V. Ceccato \& A. Newton (Eds.), Safety and Security in Transit Environments: An Interdisciplinary Approach (pp. 76-98). London: Palgrave Macmillan.

CITYCON. (2016). Butiker \& Service. Retrieved April 12, 2017, from http:// www.kistagalleria.se/stores

Clarke, R. (1989). Theoretical Background to Crime Prevention Through Environmental Design (CPTED) and Situational Prevention. In S. W. L. Hill (Ed.), Designing Out Crime (pp. 13-20). Brisbane: Australian Institute of Criminology.

Clarke, R., \& Petrossian, G. (2013). Shoplifting (2nd ed.). Problem-Oriented Guides for Police Problem-Specific Guide Series. US Department of Justice, Office of Community Oriented Policing Services, Washington, DC.

Clarke, R. V. (Ed.). (1983). Situational Crime Prevention: Its Theoretical Basis and Practical Scope. Chicago: University of Chicago Press.

Clarke, R. V. (1992). Situational Crime Prevention: Successful Case Studies. Albany: Harrow and Heston.

Cohen, L. E., \& Felson, M. (1979). Social Change and Crime Rate Trends: A Routine Activity Approach. American Sociological Review, 44(4), 588-608.

Cornish, D. B., \& Clarke, R. V. (Eds.). (2008). The Rational Choice Perspective. Cullompton: Willan.

Cozens, P., Saville, G., \& Hillier, D. (2005). Crime Prevention Through Environmental Design (CPTED): A Review and Modern Bibliography. Property Management, 23(5), 328-356.

Cozens, P. M. (2002). Sustainable Urban Development and Crime Prevention Through Environmental Design for the British City. Towards an Effective Urban Environmentalism for the 21st Century. Cities, 19(2), 129-137.

Crowe, T. (2000). Crime Prevention Through Environmental Design: Applications of Architectural Design and Space Management Concepts. Oxford: Butterworth-Heinemann. 
DeKeseredy, W. S., Donnermeyer, J. F., \& Schwartz, M. D. (2009). Toward a Gendered Second Generation CPTED for Preventing Woman Abuse in Rural Communities. Security Journal, 22(3), 178-189.

Eastman, C., Teicholz, P., Sacks, R., \& Liston, K. (2011). BIM Handbook: A Guide to Building Information Modeling for Owners, Managers, Designers, Engineers and Contractors. Hoboken: Wiley.

Eck, J., Clarke, R., \& Guerette, R. (2007). Risky Facilities: Crime Concentration in Homogeneous Sets of Establishments and Facilities. Crime Prevention Studies, 21, 225-264.

Eck, J., \& Weisburd, D. (1995). Crime Places in Crime Theory. In J. E. E. D. Weisburd (Ed.), Crime and Place (pp. 1-33). Washington: NCJ.

Ekblom, P. (1995). Less Crime, by Design. The ANNALS of the American Academy of Political and Social Science, 539(1), 114-129.

Ekblom, P. (2011). Deconstructing CPTED [...] and Reconstructing It for Practice, Knowledge Management and Research. European Journal on Criminal Policy and Research, 17(1), 7-28.

Ekblom, P. (2013). Redesigning the Language and Concepts of Crime Prevention Through Environmental Design (CPTED). Paper presented at the 6th Ajman International Urban Planning Conference 2013, United Arab Emirates. Engstad, P. A. (1975). Environmental Opportunities and the Ecology of Crime. In R. A. Silverman \& J. J. Teevan (Eds.), Crime in Canadian Society. Toronto: Butterworths.

Felson, M. (1986). Linking Criminal Choices, Routine Activities, Informal Control, and Criminal Outcomes. New York: Springer-Verlag.

Felson, M. (1995). Those Who Desincourage Crime. In J. E. Eck \& D. Weisburd (Eds.), Crime and Place (pp. 53-66). Monsey, NY: Criminal Justice Press.

Felson, M. (2002). Crime and Everyday Life. Thousand Oaks: Sage.

Felson, M. (2006). Crime and Nature. Thousand Oaks: Sage.

Glasson, J., \& Cozens, P. (2011). Making Communities Safer from Crime: An Undervalued Element in Impact Assessment. Environmental Impact Assessment Review, 31(1), 25-35.

Grip, L. (2012, October 12). Dubbelt så många köpcentrum på 15 år, 2012-1022. Skabska Dagbladet. Retrieved June 12, 2017, from http://www.skd. se/2012/10/22/dubbelt-sa-manga-kopcentrum-pa-15-ar/

Hendricks, S. A., Landsittel, D. P., Amandus, H. E., Malcan, J., \& Bell, J. (1999). A Matched Case-Control Study of Convenience Store Robbery Risk Factors. Journal of Occupational and Environmental Medicine, 41(11), 995-1104. 
Iqbal, A., \& Ceccato, V. (2016). Is CPTED Useful to Guide the Inventory of Safety in Parks? A Study Case in Stockholm, Sweden. International Criminal Justice Review, 26(2), 150-168.

Jacobs, J. (1961). The Death and Life of Great American Cities. New York: Vintage Books.

Jeffery, C. R. (1977). Crime Prevention Through Environmental Design (2nd ed.). Beverly Hills: Sage.

Johansson, E. (2016). Trygghet i Köpcentrum: En fallstudie i Stockholm, Sverige. Samhällsbyggnad Civilingenjörsexamen-Samhällsbyggnad, KTH, Stockholm.

Kajalo, S., \& Lindblom, A. (2011). An Empirical Analysis of Retail Entrepreneurs' Approaches to Prevent Shoplifting. Security Journal, 24(4), 269-282.

Kornhauser, R. (1978). Social Sources of Delinquency. Chicago: University of Chicago Press.

Lee, G., Hollinger, R. C., \& Dabney, D. A. (1999). The Relationship Between Crime and Private Security at US Shopping Centers. American Journal of Criminal Justice, 23(2), 157.

Lindblom, A., \& Kajalo, S. (2011). The Use and Effectiveness of Formal and Informal Surveillance in Reducing Shoplifting: A Survey in Sweden, Norway and Finland. The International Review of Retail, Distribution and Consumer Research, 21(2), 111-128.

Loukaitou-Sideris, A. (2012). Safe on the Move: The Importance of the Built Environment. In V. Ceccato (Ed.), The Urban Fabric of Crime and Fear (pp. 85-110). Dordrecht: Springer.

Newman, O. (1972). Defensible Space-Crime Prevention Through Urban Design. New York: Collier Books.

Pain, R. (2000). Place, Social Relations and the Fear of Crime: A Review. Progress in Human Geography, 24(3), 365-387.

Poyner, B., \& Webb, B. (1995). Reducing Theft from Shopping Bags in City Center Markets. In R. Clarke (Ed.), Situational Crime Prevention: Successful Case Studies (pp. 83-89). Albany: Harrow and Heston.

Poyser, S. (2004). Shopping Centre Design, Decline and Crime. International Journal of Police Science \& Management, 7(2), 123-125.

Rengert, G., \& Ratcliffe, J. H. (2005). Inmate Violence Against Correctional Staff: An Environmental Analysis of Risk. Philadelphia. Retrieved March 15, 2017.

Reynald, D. M., \& Elffers, H. (2009). The Future of Newman's Defensible Space Theory: Linking Defensible Space and the Routine Activities of Place. European Journal of Criminology, 6(1), 25-46. 
Sampson, R. J., Raudenbush, S. W., \& Earls, F. (1997). Neighbourhoods and Violent Crime: A Multilevel Study of Collective Efficacy. Science, 277(5328), 918-924.

Santtila, P., Laukkanen, M., \& Zappalà, A. (2007). Crime Behaviours and Distance Travelled in Homicides and Rapes. Journal of Investigative Psychology and Offender Profiling, 4(1), 1-15.

Savard, D. M., \& Kennedy, D. K. (2014). Crime and Security Liability Concerns at Shopping Centers. In K. Walby \& R. K. Lippert (Eds.), Corporate Security in the 21st Century: Theory and Practice in International Perspective. Basingstoke: Palgrave.

Saville, G. (2013). Third Generation of CPTED. Retrieved January 8, 2017, from www.alternation.ca

Schneider, R., \& Kitchen, T. (2002). Planning for Crime Prevention: A Transatlantic Perspective. London: Routledge.

Shaw, C. R., \& McKay, H. D. (1942). Juvenile Delinquency and Urban Areas. Chicago: University of Chicago Press.

Sherman, L. W., \& Weisburd, D. (1995). General Deterrent Effects of Police Patrol in Crime "Hot Spots": A Randomized, Controlled Trial. Justice Quarterly, 12(4), 625-648.

Smith, S. J. (1987). Design Against Crime? Beyond the Rhetoric of Residential Crime Prevention. Property Management, 5(2), 146-150.

Sorbring, K. (2012/2010, October 8). Sverige Förvandlas till det Nya Gallerialandet. Expressen. Retrieved March 15, 2017, from http://www.expressen.se/nyheter/dokument/sverige-forvandlas-till-det-nya-gallerialandet/

Swedish Trade Federation. (2015). Svensk Handels Undersökning om Stöldbrott i Butik 2015. Retrieved April 10, 2017, from http://www.svenskhandel.se/ globalassets/dokument/aktuellt-och-opinion/rapporter-och-foldrar/stoldbrott-i-butik-2015.pdf

Systembolaget. (2013). Vårt Uppdrag. Retrieved March 15, 2017, from https:// www.systembolaget.se/

Taylor, E. (2016). Supermarket Self-Checkouts and Retail Theft: The Curious Case of the SWIPERS. Criminology \& Criminal Justice, 16(5), 552-567.

Weisburd, D., \& Amram, S. (2014). The Law of Concentrations of Crime at Place: The Case of Tel Aviv-Jaffa. Police Practice and Research, 15(2), 101-114. Weisburd, D., Morris, N., \& Groff, E. (2009). Hot Spots of Juvenile Crime: A Longitudinal Study of Arrest Incidents at Street Segments in Seattle, Washington. Journal of Quantitative Criminology, 25(4), 443-467. 
Welsh, B. C., \& Farrington, D. P. (2009). Public Area CCTV and Crime Prevention: An Updated Systematic Review and Meta-Analysis. Justice Quarterly, 26(4), 716-745.

Wiles, P., \& Costello, A. (2000). The 'Road to Nowhere': The Evidence for Travelling Criminals. Home Office Research Study, London: Home Office.

Open Access This chapter is licensed under the terms of the Creative Commons Attribution 4.0 International License (http://creativecommons.org/licenses/ by/4.0/), which permits use, sharing, adaptation, distribution and reproduction in any medium or format, as long as you give appropriate credit to the original author(s) and the source, provide a link to the Creative Commons license and indicate if changes were made.

The images or other third party material in this chapter are included in the chapter's Creative Commons license, unless indicated otherwise in a credit line to the material. If material is not included in the chapter's Creative Commons license and your intended use is not permitted by statutory regulation or exceeds the permitted use, you will need to obtain permission directly from the copyright holder.

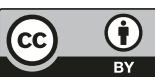

